\title{
LITERATURE AND THE
}

REMAINS OF THE

DEATH PENALTY 
INVENTING WRITING THEORY

Jacques Lezra and Paul North, series editors 


\section{LITERATURE AND THE REMAINS OF THE DEATH PENALTY}

PEGGY KAMUF

Fordham University Press New York 2019 
Copyright (C) 2019 Fordham University Press

All rights reserved. No part of this publication may be reproduced, stored in a retrieval system, or transmitted in any form or by any means-electronic, mechanical, photocopy, recording, or any other-except for brief quotations in printed reviews, without the prior permission of the publisher.

Fordham University Press has no responsibility for the persistence or accuracy of URLs for external or third-party Internet websites referred to in this publication and does not guarantee that any content on such websites is, or will remain, accurate or appropriate.

Fordham University Press also publishes its books in a variety of electronic formats. Some content that appears in print may not be available in electronic books.

Visit us online at www.fordhampress.com.

Library of Congress Cataloging-in-Publication Data

Names: Kamuf, Peggy, 1947-author.

Title: Literature and the remains of the death penalty / Peggy Kamuf. Description: First edition. | New York : Fordham University Press, 2019. |

Series: Idiom: inventing writing theory | Includes bibliographical references and index.

Identifiers: LCCN 2018010819| ISBN 9780823282302 (cloth : alk. paper) | ISBN 9780823282296 (pbk. : alk. paper)

Subjects: LCSH: Capital punishment in literature. | American fiction-20th century-History and criticism.

Classification: LCC PS374.C357 K36 2019 | DDC 809/.933556-dc23

LC record available at https://ccn.loc.gov/2018010819

Printed in the United States of America

\section{$\begin{array}{llllllll}21 & 20 & 19 & 5 & 4 & 3 & 2 & 1\end{array}$}

First edition 